Washington University School of Medicine Digital Commons@Becker

\title{
Global proteomics analysis of circulating extracellular vesicles isolated from lung transplant recipients
}

\author{
Sandhya Bansal \\ St. Joseph's Hospital and Medical Center \\ Marissa McGilvrey \\ Translational Genomics Research Institute \\ Krystine Garcia-Mansfield \\ Translational Genomics Research Institute \\ Ritin Sharma \\ Translational Genomics Research Institute \\ Ross M. Bremner \\ St. Joseph's Hospital and Medical Center
}

See next page for additional authors

Follow this and additional works at: https://digitalcommons.wustl.edu/open_access_pubs

Please let us know how this document benefits you.

\author{
Recommended Citation \\ Bansal, Sandhya; McGilvrey, Marissa; Garcia-Mansfield, Krystine; Sharma, Ritin; Bremner, Ross M.; Smith, \\ Michael A.; Hachem, Ramsey; Pirrotte, Patrick; and Mohanakumar, Thalachallour, "Global proteomics \\ analysis of circulating extracellular vesicles isolated from lung transplant recipients." ACS Omega. 5, 24. \\ 14360 - 14369. (2020). \\ https://digitalcommons.wustl.edu/open_access_pubs/9228
}

This Open Access Publication is brought to you for free and open access by Digital Commons@Becker. It has been accepted for inclusion in Open Access Publications by an authorized administrator of Digital Commons@Becker. For more information, please contact vanam@wustl.edu. 


\section{Authors}

Sandhya Bansal, Marissa McGilvrey, Krystine Garcia-Mansfield, Ritin Sharma, Ross M. Bremner, Michael A. Smith, Ramsey Hachem, Patrick Pirrotte, and Thalachallour Mohanakumar 


\section{Global Proteomics Analysis of Circulating Extracellular Vesicles Isolated from Lung Transplant Recipients}

Sandhya Bansal, Marissa McGilvrey, Krystine Garcia-Mansfield, Ritin Sharma, Ross M. Bremner, Michael A. Smith, Ramsey Hachem, Patrick Pirrotte, and Thalachallour Mohanakumar*

Cite This: ACS Omega 2020, 5, 14360-14369

Read Online

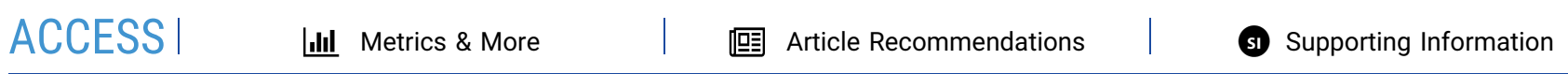

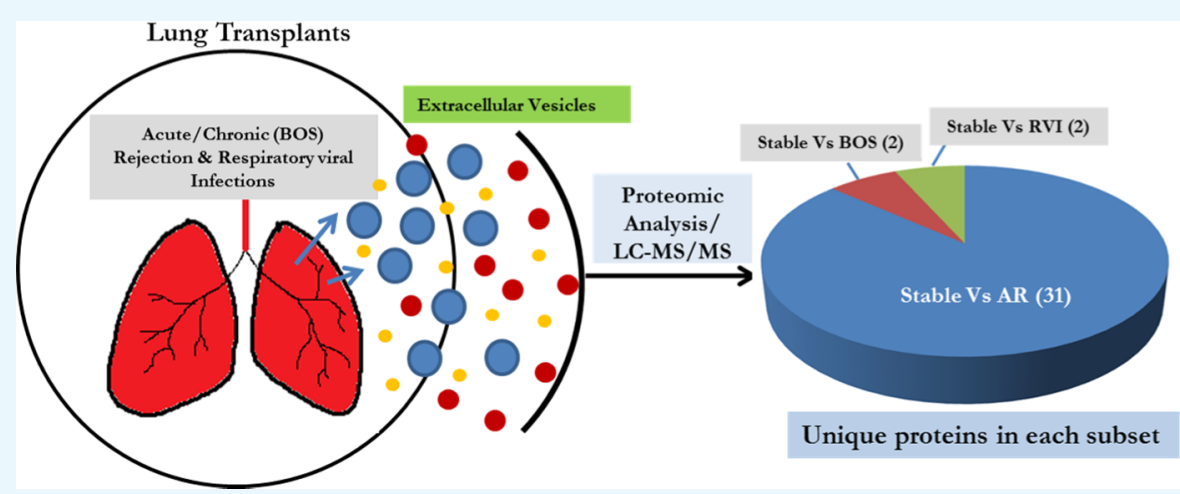

ABSTRACT: Lung transplant recipients (LTxRs) with acute rejection (AR) and chronic rejection (bronchiolitis obliterans syndrome $[\mathrm{BOS}]$ ) induce circulating exosomes known to contain donor human leukocyte antigens and lung-associated self-antigens. Here, we sought to identify proteomic signatures in circulating extracellular vesicles (EVs) that differentiate LTxRs in 4 groups: stable, AR, BOS, or respiratory viral infection (RVI). EVs were isolated from plasma from patients in each group via ultracentrifugation. EV protein cargoes were prepared for shotgun proteomics using liquid chromatography-tandem mass spectrometry. We identified 2 unique proteins for AR, 4 for RVI, 24 for BOS, and 8 for stable LTxRs. Differential analysis of AR, BOS, RVI, and stable proteins identified significantly deregulated proteins $\left(p<0.05, \log _{2}\right.$ (fold change) $\left.> \pm 1\right)$ in each condition $(31$, 2, and 2, respectively). EVs from LTxRs with AR contained proteins involved in immunoglobulin, complement regulation, coagulation, and innate and adaptive immune response pathways. EVs from LTxRs with BOS revealed enriched immunoglobulin receptors and a carboxypeptidase $\mathrm{N}$ catalytic chain. EVs from LTxRs with RVI had an enriched macrophage-stimulating factor. We found unique signatures in LTxRs with AR, BOS, and RVI, highlighting complex immune mechanisms underlying lung allograft rejection. Proteomic signatures in LTxRs' circulating EVs provided insights into immunological mechanisms of graft rejection and RVI.

\section{INTRODUCTION}

Lung transplantation $(\mathrm{LTx})$ is a treatment option for patients with end-stage respiratory disease such as idiopathic pulmonary fibrosis, chronic obstructive pulmonary disease, cystic fibrosis, and other interstitial lung disease. Despite immunosuppressive measures, post-LTx recovery can be challenged by acute rejection (AR) or chronic rejection. The median survival after LTx is just 5.8 years, and this is the shortest survival compared with all other solid organ transplants, results primarily from chronic rejection. ${ }^{2}$ Several risk factors for $\mathrm{AR}$ or chronic rejection have been proposed, including immune responses to human leukocyte antigen (HLA), development of donor-specific antibody (DSA) against HLA, immune response to lung-associated self-antigens (SAgs), and respiratory viral infection (RVI). ${ }^{3-5}$ The contribution and interplay of factors underlying each of these mechanisms in modulating the immune responses of LTx recipients (LTxRs) has not been fully characterized. ${ }^{6}$

Extracellular vesicles (EVs) play an important role in defining the immunopathogenesis of lung disease. ${ }^{7}$ EVs are a family of particles released by cells, and they are involved in various physiological functions. EVs vary in size, morphology, and content and are classified based on the mechanism of their release. Exosomes, which are membrane-bound EVs, result from the fusion of late endosomes with the plasma membrane

Received: February 26, 2020

Accepted: May 27, 2020

Published: June 12, 2020

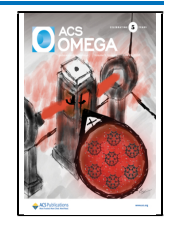


( $<200 \mathrm{~nm}$ in diameter), whereas microvesicles and apoptotic bodies (typically 200-1000 $\mathrm{nm}$ in diameter) are the result of vertical trafficking of molecules to the plasma membrane, where molecules are shed in the form of EVs into the extracellular space. Several reports demonstrated that EVs carry a diverse cargo of proteins, lipids, metabolites, and RNAs (mRNAs and noncoding RNAs, including microRNAs). ${ }^{8}$ EVs have also been shown to contribute to intercellular communication, with critical roles in cancer, the spread of infection, and physiological processes such as stress, inflammation, wound healing, coagulation, and angiogenesis. ${ }^{9} \mathrm{We}$ recently reported that circulating exosomes isolated from LTxRs with AR or bronchiolitis obliterans syndrome (BOS) contain DSA, lung SAgs, major histocompatibility complex class II molecules, costimulatory molecules CD80 and CD86, transcription factor NF-kB, CIITA, and $20 \mathrm{~S}$ proteasome. ${ }^{10}$ However, the biological functions and fate of EVs released after LTx remain unknown. The goal of this study is to identify, compare, and contrast proteomic signatures in the circulating EVs isolated from LTxRs diagnosed with AR, RVI, or BOS vs stable LTxRs, using mass spectrometry to clarify the molecular mechanisms underlying lung allograft rejection.

\section{RESULTS AND DISCUSSION}

2.1. EV Protein Cargo Characterization in LTxRs. Proteomic analysis of circulating EVs identified a total of 2834 peptides mapping to 236 nonredundant proteins. Overall, 136 proteins $(57.6 \%)$ were common to all conditions (Figure 1)

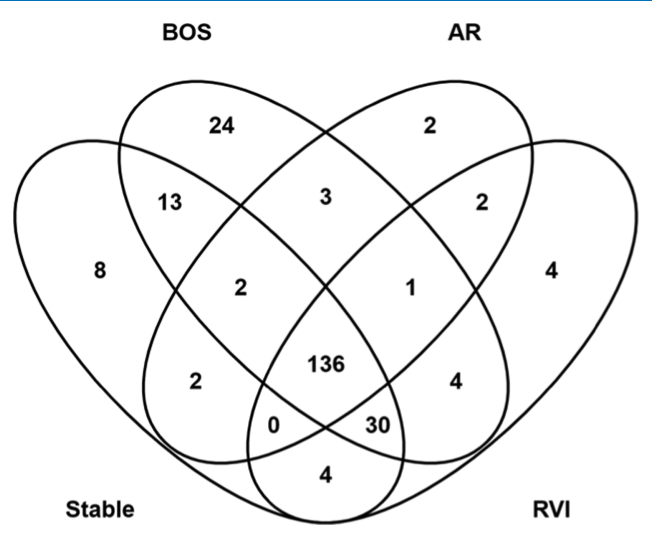

Figure 1. Venn diagram of proteins identified in extracellular vesicles isolated from patients in 4 conditions after lung transplant. Abbreviations: AR, acute rejection; BOS, bronchiolitis obliterans syndrome; and RVI, respiratory viral infection.

and $8,24,2$, and 4 proteins were unique to LTxRs in the stable, BOS, AR, and RVI groups, respectively. An average of 164 proteins was identified in BOS $(n=3)$ with an average of $78 \%$ mapping to ExoCarta. In patients with $\mathrm{AR}(n=3)$, an average of 128 proteins was identified and $79 \%$ were present in ExoCarta. An average of 145 proteins was identified in RVI ( $n$ $=3$ ) and $76 \%$ were in ExoCarta. For stable patients $(n=5)$, an average of 143 proteins was identified with $79 \%$ annotated in ExoCarta. (Table 1). Eight proteins uniquely identified in EVs from stable LTxRs (ACTR2, EFEMP1, IGKV1-16, IGKV1D39, IGLV2-23, GNL1, PFKP, and S100-A12; Figure 1 and Table 2) are involved in the transport of small molecules, signal transduction, hemostasis, and extracellular matrix organization. Two proteins uniquely identified in AR
Table 1. Total Protein Identifications in EVs from Patients Post LTx ${ }^{a}$

\begin{tabular}{lccc} 
group & total peptides & total proteins & proteins mapped to ExoCarta (\%) \\
\hline BOS & 2793 & 138 & $114(83)$ \\
& 3245 & 190 & $145(76)$ \\
\multirow{4}{*}{ AR } & 3211 & 163 & $124(76)$ \\
& 2373 & 122 & $99(81)$ \\
& 2636 & 137 & $103(75)$ \\
RVI & 2451 & 125 & $100(80)$ \\
& 3190 & 161 & $126(78)$ \\
\multirow{3}{*}{ stable } & 2828 & 137 & $103(75)$ \\
& 2867 & 137 & $103(75)$ \\
& 2547 & 135 & $108(80)$ \\
& 3136 & 166 & $125(75)$ \\
& 2788 & 142 & $102(72)$ \\
& 2790 & 137 & $117(85)$ \\
& 2824 & 135 & $108(80)$
\end{tabular}

${ }^{a}$ Abbreviations: EVs, extracellular vesicles; LTx, lung transplant; BOS, bronchiolitis obliterans syndrome; AR, acute rejection; RVI, respiratory viral infection.

(CFHR2 and IGKV1-33; Figure 1 and Table 2) are associated with immunoglobulin and complement regulation.

The 24 proteins uniquely identified in LTxRs with BOS (ATP2A3, CANX, CD36, CPB2, ENDOD1, F9, GANAB, GP1BB, HIST1H4A, HSPA5, IGHV1-3, IGKV3D-20, IGLV4-60, ITGA6, ITGB1, MYH9, MYL6, PDIA3, PF4, PSMA2, PSMA7, PTGS1, TTYH3, and YWHAZ; Figure 1 and Table 2) are associated with immune activation, including immunoglobulin synthesis, programmed cell death, and DNA repair. EVs from LTxRs with RVI harbored 4 unique proteins (GPX3, HSPG2, IGHD, and IGLV9-49; Figure 1 and Table 2) linked to macrophage and immune activation.

2.2. Differential Analysis of EV Proteomes from LTxR Subgroups. Differential analysis across stable LTxRs and those with BOS, AR, and RVI revealed significantly $(p<0.05$, $\log _{2}$ fold change $(\mathrm{FC})> \pm 1$ ) upregulated or downregulated proteins listed in Table 3 and visualized on the volcano plots (Figure 2). BOS showed an increase in the carboxypeptidase $\mathrm{N}$ catalytic chain (CPN1, $p=0.01)$ and a decrease in the polymeric immunoglobulin receptor (PIGR, $p=0.02$ ), while AR showed an increase in several complement proteins including C3 $(p=0.006)$, C6 $(p=0.0009)$, C7 $(p=0.01)$, CFI $(p=0.005), \mathrm{CFB}(p=0.03), \mathrm{CFH}(p=0.03)$, and C8B $(p$ $=0.04)$ and a decrease in immunoglobulin-associated proteins (IGLV2-18 $(p=0.01)$, IGLV7-46 $(p=0.01)$, and IGKV6D-21 $(p=0.04))$. EVs from LTxRs with RVI identified two differentially abundant proteins: macrophage-stimulating protein (MST1) (increased, $p=0.01$ ) and IGCL7 (immunoglobulin lambda constant 7) (decreased, $p=0.04$ ).

Unsupervised clustering (Supporting Information, Figure S1) of the 35 significant differentially abundant proteins showed that the AR patients have a very distinct abundance profile of these proteins compared to the other LTxR conditions while a wide heterogeneity persists between other LTxR conditions. Details on proteins used for each pairwise analysis are provided in Supporting Information, Table S1.

2.3. LTxR-Derived EVs Contain Distinct Functional Signatures. Gene set enrichment analysis (GSEA) identified pathways and biological processes enriched in stable LTxRs and LTxRs with AR, BOS, or RVI (Figure 3). In LTxRs with $A R$, upregulated proteins contributed to a positive enrichment 
Table 2. Unique Proteins in Each LTx Condition ${ }^{a}$

\begin{tabular}{|c|c|c|c|c|c|c|}
\hline $\begin{array}{l}\text { LTxR } \\
\text { group }\end{array}$ & $\begin{array}{l}\text { uniprot } \\
\text { accession }\end{array}$ & gene & description & $\begin{array}{l}\text { molecular } \\
\text { function }\end{array}$ & biological role & $\begin{array}{c}\text { \# of } \\
\text { patients }\end{array}$ \\
\hline \multirow[t]{24}{*}{$\begin{array}{l}\mathrm{BOS} \\
(N=3)\end{array}$} & Q93084-4 & ATP2A3 & $\begin{array}{l}\text { sarcoplasmic/endoplasmic reticulum calcium } \\
\text { ATPase } 3\end{array}$ & translocase & calcium transport & 1 \\
\hline & P05556 & ITGB1 & integrin $\beta$-1 & receptor & cell adhesion & 1 \\
\hline & P16671-4 & CD36 & platelet glycoprotein 4 & receptor & cell adhesion & 1 \\
\hline & P23229-7 & ITGA6 & Integrin $\alpha-6$ & receptor & cell adhesion & 1 \\
\hline & P35579 & MYH9 & myosin-9 & actin binding & cell adhesion & 1 \\
\hline & P02776 & PF4 & platelet factor 4 & cytokine & chemotaxis & 1 \\
\hline & $\mathrm{O} 14818$ & PSMA7 & proteasome subunit $\alpha$ type-7 & hydrolase & $\begin{array}{l}\text { component of the } 20 \mathrm{~S} \text { core } \\
\text { proteasome complex }\end{array}$ & 1 \\
\hline & P25787 & PSMA2 & proteasome subunit $\alpha$ type- 2 & hydrolase & $\begin{array}{l}\text { component of the } 20 \mathrm{~S} \text { core } \\
\text { proteasome complex }\end{array}$ & 1 \\
\hline & P62805 & $\mathrm{H} 4 \mathrm{C} 1$ & histone $\mathrm{H} 4$ & DNA binding & core component of nucleosome & 1 \\
\hline & Q14697 & GANAB & neutral $\alpha$-glucosidase $\mathrm{AB}$ & hydrolase & glycan metabolism & 1 \\
\hline & P00740-2 & F9 & coagulation factor IX & hydrolase & hemostasis & 1 \\
\hline & P13224 & GP1BB & platelet glycoprotein $\mathrm{Ib} \beta$ chain & protein binding & hemostasis & 1 \\
\hline & Q96IY4 & $\mathrm{CPB} 2$ & carboxypeptidase B2 & hydrolase & hemostasis & 1 \\
\hline & A0A075B6I1 & IGLV4-60 & immunoglobulin lambda variable $4-60$ & antigen binding & immunity & 1 \\
\hline & A0A0C4DH25 & $\begin{array}{l}\text { IGKV3D- } \\
20\end{array}$ & immunoglobulin kappa variable 3D-20 & antigen binding & immunity & 1 \\
\hline & A0A0C4DH29 & IGHV1-3 & immunoglobulin heavy variable $1-3$ & antigen binding & immunity & 1 \\
\hline & Q9C0H2-3 & ТТYН3 & protein tweety homolog 3 & ion channel & ion transport & 1 \\
\hline & P23219-4 & PTGS1 & prostaglandin $\mathrm{G} / \mathrm{H}$ synthase 1 & dioxygenase & lipid metabolism & 1 \\
\hline & O94919 & ENDOD1 & endonuclease domain-containing 1 protein & $\begin{array}{l}\text { endonuclease } \\
\text { activity }\end{array}$ & platelet degranulation & 1 \\
\hline & P30101 & PDIA3 & protein disulfide-isomerase $\mathrm{A} 3$ & isomerase & protein folding & 1 \\
\hline & P11021 & HSPA5 & endoplasmic reticulum chaperone $\mathrm{BiP}$ & chaperone & $\begin{array}{l}\text { protein folding and quality } \\
\text { control }\end{array}$ & 1 \\
\hline & P27824-3 & CANX & calnexin & chaperone & $\begin{array}{l}\text { protein folding and quality } \\
\text { control }\end{array}$ & 1 \\
\hline & P60660-2 & MYL6 & myosin light polypeptide 6 & motor protein & regulatory light chain of myosin & 1 \\
\hline & P63104 & YWHAZ & 14-3-3 protein zeta/delta & adapter protein & signal transduction & 1 \\
\hline \multirow{2}{*}{$\begin{array}{l}\mathrm{AR} \\
(N=3)\end{array}$} & P01594 & IGKV1-33 & immunoglobulin kappa variable $1-33$ & antigen binding & immunity & 1 \\
\hline & P36980-2 & CFHR2 & complement factor $\mathrm{H}$-related protein 2 & protein binding & $\begin{array}{l}\text { regulation of complement } \\
\text { activation }\end{array}$ & 1 \\
\hline \multirow{4}{*}{$\begin{array}{l}\mathrm{RVI} \\
\qquad(N=3)\end{array}$} & A0A0B4J1Y8 & IGLV9-49 & immunoglobulin lambda variable 9-49 & antigen binding & immunity & 1 \\
\hline & P01880 & IGHD & immunoglobulin heavy constant delta & antigen binding & immunity & 1 \\
\hline & P22352 & GPX3 & glutathione peroxidase 3 & oxidoreductase & $\begin{array}{l}\text { cellular response to oxidative } \\
\text { stress }\end{array}$ & 2 \\
\hline & P98160 & HSPG2 & $\begin{array}{l}\text { basement membrane-specific heparan sulfate } \\
\text { proteoglycan core protein }\end{array}$ & $\begin{array}{l}\text { amyloid- } \beta \\
\text { binding }\end{array}$ & angiogenesis & 1 \\
\hline \multirow[t]{8}{*}{$\begin{array}{l}\text { stable } \\
\qquad(N=5)\end{array}$} & P04432 & $\begin{array}{l}\text { IGKV1D- } \\
39\end{array}$ & immunoglobulin kappa variable 1D-39 & antigen binding & immunity & 2 \\
\hline & P01705 & IGLV2-23 & immunoglobulin lambda variable $2-23$ & antigen binding & immunity & 1 \\
\hline & P04430 & IGKV1-16 & immunoglobulin kappa variable $1-16$ & antigen binding & Immunity & 1 \\
\hline & P80511 & S100-A12 & Protein S100-A12 & metal binding & immunity & 1 \\
\hline & Q01813-2 & PFKP & $\begin{array}{l}\text { ATP-dependent 6-phosphofructokinase, platelet } \\
\text { type }\end{array}$ & ATP binding & glycolysis & 1 \\
\hline & P61160 & ACTR2 & actin-related protein 2 & actin binding & constituent of ARP2/3 complex & 1 \\
\hline & P36915-2 & GNL1 & guanine nucleotide-binding protein-like 1 & GTPase activity & signal transduction & 1 \\
\hline & Q12805-5 & EFEMP1 & $\begin{array}{l}\text { EGF-containing fibulin-like extracellular matrix } \\
\text { protein } 1\end{array}$ & $\begin{array}{l}\text { EGF and EGFR } \\
\text { binding }\end{array}$ & signal transduction & 1 \\
\hline
\end{tabular}

${ }^{a}$ Proteins present in 3 out of 3 technical replicates for each patient were compared. Proteins unique to a LTx group are presented, with the number of patients each protein was identified in. Functional information is taken from protein annotation in the Uniprot database.

of 4 gene sets (hallmark coagulation, innate immune system, regulation of intracellular transduction, and activation of immune response). Downregulated proteins were associated with a negatively enriched functional gene set (small molecule metabolic process; Figure 3A).

Fifteen gene sets were significantly enriched in LTxRs with BOS (Figure 3B). Twelve sets were negatively enriched in LTxRs with BOS; of these, 2 gene sets are associated with cellular death. The top 3 negatively enriched sets are associated with catabolic processes. Of the 3 positively enriched sets, 2 are associated with regulation of the extracellular matrix (matrisome-associated and extracellular matrix regulators) and the third is associated with complement system response (lectin pathway).

In LTxRs with RVI, GSEA identified 10 positively and 2 negatively enriched gene sets, associated with upregulated and downregulated proteins, respectively (Figure 3C). Four of the positively enriched sets are associated with lipid metabolism 
Table 3. Significant Differentially Abundant Proteins in EVs of LTxRs: Significant Differentially Abundant Proteins $(p<$ 0.05 and $\log _{2}($ FC) $> \pm 1)$ in Each Rejection Condition Compared to Stable ${ }^{a}$

\begin{tabular}{|c|c|c|c|}
\hline \multicolumn{4}{|c|}{ LTxRs with AR vs stable LTxRs } \\
\hline gene names & $p$-value & $p$-Adj $(\mathrm{BH})$ & $\log _{2}(\mathrm{FC})$ \\
\hline C6 & 0.001 & 0.0834 & 1.312 \\
\hline AMBP & 0.0025 & 0.055 & 1.295 \\
\hline FBLN1 & 0.0026 & 0.0767 & 1.169 \\
\hline ITIH4 & 0.003 & 0.1732 & 1.795 \\
\hline CFI & 0.0054 & 0.0973 & 1.745 \\
\hline $\mathrm{C} 3$ & 0.0064 & 0.0808 & 1.443 \\
\hline APOC3 & 0.0077 & 0.0934 & 1.799 \\
\hline VWF & 0.0103 & 0.1732 & 1.395 \\
\hline $\mathrm{C} 7$ & 0.0115 & 0.0371 & 1.492 \\
\hline $\mathrm{CFB}$ & 0.0364 & 0.0543 & 1.055 \\
\hline $\mathrm{CFH}$ & 0.0382 & 0.0543 & 1.116 \\
\hline ECM1 & 0.0419 & 0.1732 & 1.522 \\
\hline F11 & 0.0431 & 0.1732 & 1.372 \\
\hline ITIH1 & 0.044 & 0.1732 & 1.104 \\
\hline $\mathrm{C} 8 \mathrm{~B}$ & 0.0477 & 0.1732 & 1.109 \\
\hline CLU & 0.0001 & 0.1732 & -1.247 \\
\hline VTN & 0.0011 & 0.134 & -1.451 \\
\hline GAPDH & 0.0012 & 0.1732 & -3.914 \\
\hline PON1 & 0.0036 & 0.0178 & -1.805 \\
\hline KLKB1 & 0.0079 & 0.0834 & -1.313 \\
\hline IGLV2-18 & 0.0179 & 0.1732 & -2.568 \\
\hline IGLV7-46 & 0.0181 & 0.1732 & -1.8 \\
\hline APOA1 & 0.02 & 0.0371 & -1.162 \\
\hline IGLC7 & 0.0295 & 0.1279 & -1.201 \\
\hline VTN & 0.0303 & 0.0578 & -3.215 \\
\hline IGLV1-40 & 0.0322 & 0.1732 & -1.114 \\
\hline APOA2 & 0.035 & 0.1732 & -1.412 \\
\hline IGHM & 0.0353 & 0.1279 & -1.421 \\
\hline АСТВ & 0.0361 & 0.1732 & -2.068 \\
\hline IGKV6D-21 & 0.0445 & 0.1732 & -2.414 \\
\hline TLN1 & 0.0477 & 0.0371 & -3.413 \\
\hline \multicolumn{4}{|c|}{ LTxRs with BOS vs Stable LTxRs } \\
\hline CPN1 & 0.0141 & 0.945 & 1.134 \\
\hline PIGR & 0.0243 & 0.945 & -1.403 \\
\hline \multicolumn{4}{|c|}{ LTxRs with RVI vs Stable LTxRs } \\
\hline MST1 & 0.0109 & 0.865 & 1.363 \\
\hline IGLC7 & 0.0407 & 0.865 & -1.324 \\
\hline
\end{tabular}

${ }^{a}$ Abbreviations: EVs, extracellular vesicles; LTx, lung transplant; LTxRs, lung transplant recipients, AR, acute rejection; BOS, bronchiolitis obliterans syndrome; RVI, respiratory viral infection.

(regulation of the lipid metabolic process, cellular lipid metabolic process, lipid metabolic process, and regulation of lipid localization). The 2 negatively enriched sets are associated with immune response (innate immune system and defense response to bacterium).

Across the 3 GSEA analyses, only two enriched gene sets were shared between LTxRs with rejection; the innate immune system is positively enriched in the setting of AR and is negatively enriched in LTxRs with RVI. Negative regulation of cellular component organization is negatively enriched in LTxRs with BOS and is positively enriched in LTxRs with RVI.

2.4. Validation of Key Proteins in Each Clinical Condition Using Immunoblot. To validate our findings by Western blot, we selected several differentially abundant proteins ( $\mathrm{C} 3$ for $\mathrm{AR}, \mathrm{CPN} 1$ for BOS, and MST1 for RVI). C3 was present in EVs from AR samples, which are $~ 2.3$-fold higher as compared to EVs from stable samples (Figure 4a,d). CPN1 was present in 4.0-fold higher quantities in EVs from BOS than stable (Figure 4b,e). MST1 was 7.0 -fold increased in RVI compared to stable patients (Figure 4c,f). Differential abundance of MST1 in RVI, C3 in AR samples, and CPN1 in BOS was statistically significant $(p \leq 0.005)$ compared to stable. However, we have done Western blots of MV isolated from normal and did not detect any of the key proteins what we identified post LTx (collagen $\mathrm{V}$ and $\mathrm{K} \alpha_{1}$ tubulin).

We previously published our observation of increased levels of donor HLA, lung SAgs, transcription factor NF-K $\beta$, CIITA, and $20 S$ proteasome in circulating exosomes of LTxRs with AR and BOS. ${ }^{10,11}$ In the current study, we demonstrated that circulating EVs from LTxRs with AR contained significantly increased levels of immunoglobulin and complement regulatory proteins, along with coagulation factors and plasminogen, compared to stable LTxRs. A report by Naesens et al. ${ }^{12}$ showed that renal transplant biopsies classified as cellular rejection contain B lymphocytes capable of producing antibodies (Abs) against donor antigens, along with $\mathrm{C} 3$, CD20, and peritubular deposition of C4D. In agreement, our results also showed humoral-pathway activation in LTxRs diagnosed with cellular AR. We demonstrated the upregulation of proteins associated with complement, immunoglobulins, coagulation, and inflammation in LTxRs with cellular rejection. Complement activation is known to have a strong correlation with tissue injury and antibody-mediated rejection, ${ }^{13}$ and our results suggest that complement-mediated tissue injury can occur even in patients diagnosed with cellular rejection. Furthermore, our result raises the possibility that complement proteins in circulating EVs can be markers to differentiate cellular rejection with a mixed phenotype (i.e., cellular and humoral) from only having a cellular phenotype.

Extracellular vesicles isolated from LTxRs with BOS showed increased amounts of CPN1, a zinc metalloprotease with a known protective function against vasoactive and inflammatory peptides. ${ }^{14}$ CPN levels are associated with complement activation; therefore, higher levels of CPN1 in LTxRs with BOS indicate increased complement activation. EVs from LTxRs with BOS also showed altered levels of PIGR. PIGR binds and transports polymeric immunoglobulin $\mathrm{A}$ and immunoglobulin $\mathrm{M}$ across the epithelial barrier to mucosal surfaces. ${ }^{\text {} 5}$ Studies have shown that gastroesophageal reflux increases the risk of BOS after LTx. ${ }^{16}$ We therefore propose that PIGR may be a contributing factor for gastroesophageal reflux disease (GERD), increasing the risk of BOS.

Extracellular vesicles isolated from LTxRs with symptomatic RVI (e.g., respiratory syncytial virus, coronavirus, rhinovirus, and influenza virus) showed significantly increased levels of MST1, a macrophage-stimulating protein also known as hepatocyte growth factor-like protein, compared to stable LTxRs. ${ }^{17}$ MST $1 / 2$ is a mediator of innate immune response ${ }^{18}$ against viruses, eliciting macrophage phagocytosis as well as cytokines and production of reactive oxygen species. Upregulation of MST1 in EVs isolated from LTxRs with RVI suggests that circulating EVs can be involved in the activation of innate immune responses, which leads to increased cytokine and reactive oxygen species production toward controlling the infection. MST1 is also likely to play an important role in lung tissue regeneration after RVI, as suggested by Narasaraju et al. ${ }^{19}$ Thus, our finding of increased levels of MST1 in EVs from LTxRs with RVI strongly suggests 

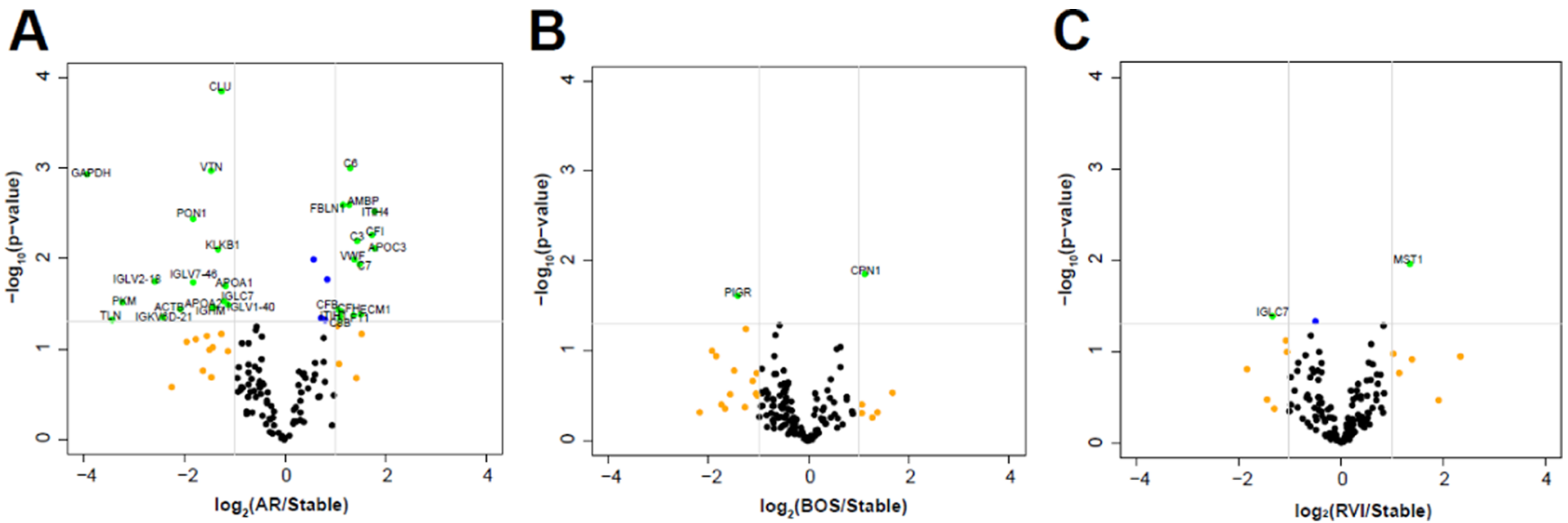

Figure 2. Volcano plots of differentially abundant proteins in LTxRs. $\log _{2}(\mathrm{FC})$ vs $-\log _{10}(p$-value) for (A) AR vs stable, (B) BOS vs stable, and (C) RVI vs stable. Green dots $\left(-\log _{10}(p\right.$-value $)>1.301$ and $\left.\log _{2}(\mathrm{FC})> \pm 1\right)$. Orange dots $\left(\log _{2}(\mathrm{FC})> \pm 1\right)$. Blue $\left(-\log _{10}(p\right.$-value $\left.)>1.301\right)$. Abbreviations: AR, acute rejection; BOS, bronchiolitis obliterans syndrome; and RVI, respirataory viral infection.

A

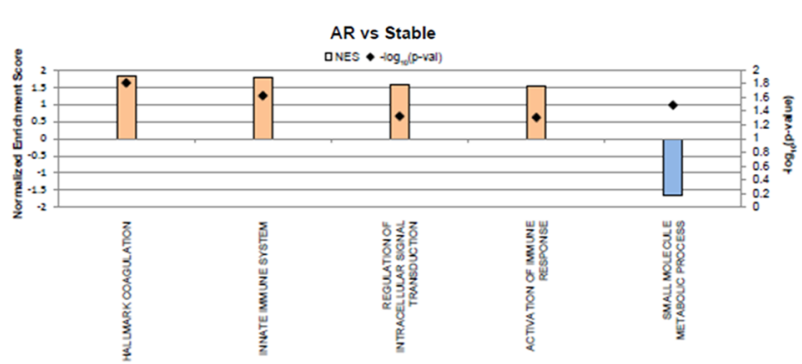

B

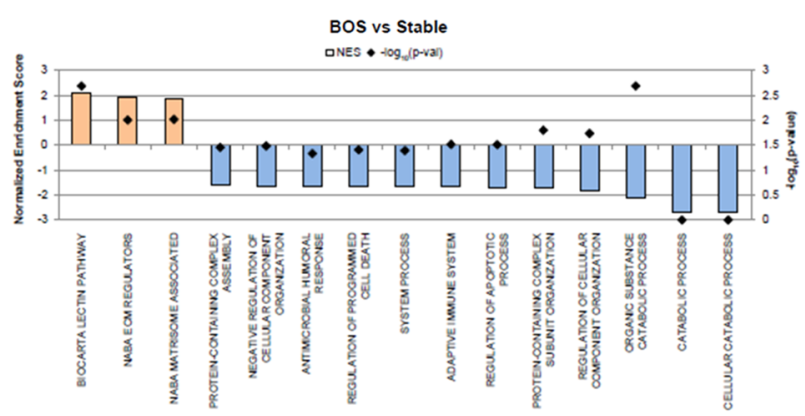

C

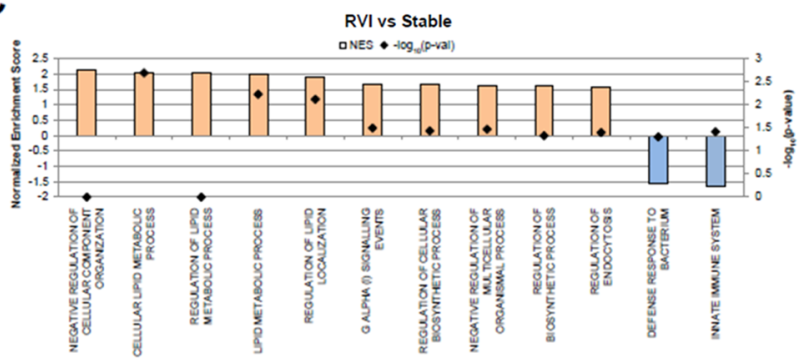

Figure 3. Significantly enriched GSEA-enriched ( $p$-value $<0.05)$ terms from gene ontology biological processes (GOBP) associated with the 3 described conditions vs stable LTxRs. (A) AR vs stable, (B) BOS vs stable, and (C) RVI vs stable. Abbreviations: AR, acute rejection; BOS, bronchiolitis obliterans syndrome; and RVI, respiratory viral infection. The computed normalized enrichment score shows GOBP terms that are increased (orange) or decreased (blue).

that this protein may be involved in the repair of damaged lung epithelium caused by a viral infection. Furthermore, we propose that in LTxRs, MST1 contained in EVs can be used as a protein signature specific to RVI and could be a useful marker for the challenging differential diagnosis of RVI from acute cellular rejection.

We are identifying proteins in the EV, which are diagnostic for AR, BOS, and RVI. However, these samples were obtained at the time of diagnosis. Further studies are needed to determine the value of these proteins in the $\mathrm{EV}$ as a noninvasive biomarker, which will require testing serial samples from a larger cohort. Further, chronic rejection following human LTx is now termed as chronic lung allograft dysfunction, which consists of restrictive allograft syndrome (RAS) and BOS. During this study, we have analyzed only BOS but not RAS and therefore further analysis of EV from RAS needs to be carried out to determine the potential value of unique proteins that may be present in RAS, which may provide further clues to the pathogenesis of RAS vs BOS.

The low number of LTxR specimens from which EVs were characterized is a limitation of this study. This is particularly true for LTxRs with AR, as our data suggest a mixed cellular and humoral phenotype for the LTxRs with AR analyzed thus far. Therefore, follow-up studies should include additional LTxRs diagnosed either with cellular rejection or antibodymediated rejection. Another shortcoming of this study is that we analyzed only rhinovirus, coronavirus, and metapneumovirus. Inclusion of LTxRs with other common infections associated with increased risk for BOS (e.g., respiratory syncytial virus and cytomegalovirus) should be considered in future analysis. According to guidelines from the International Society for Heart and Lung Transplantation, chronic lung allograft dysfunction is classified as BOS or RAS, and our analysis has been restricted only to BOS. ${ }^{24}$

\section{CONCLUSIONS}

The presence of unique proteins and their association with pathways in the EVs isolated from plasma samples of LTxRs with AR, BOS, and RVI provide important mechanistic information about rejection after LTx. In summary, proteomic findings from this study clearly demonstrate not only novel mechanisms for rejection but also the potential of EV protein cargo to distinguish different forms of AR (cellular vs humoral vs mixed). Our results highlight the role of immunoglobulins and complement proteins in BOS, which emphasizes the importance of $\mathrm{Abs}$ in the pathogenesis of BOS. The abundance 
C3

(a)

(b)

(c)

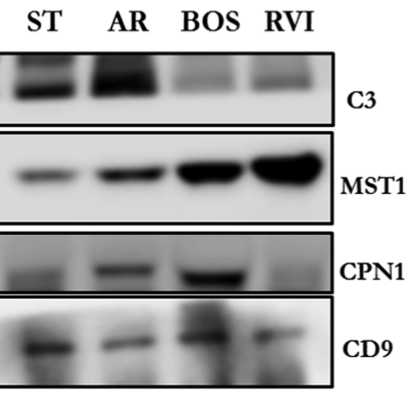

(d)
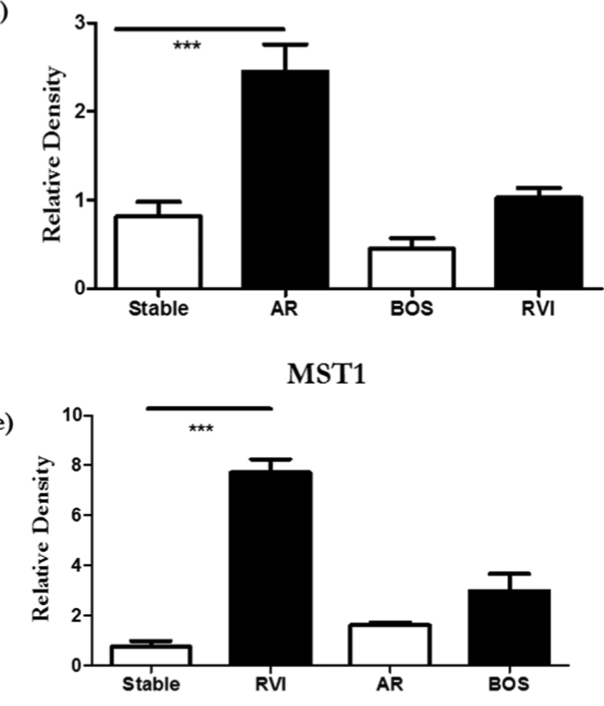

(f)

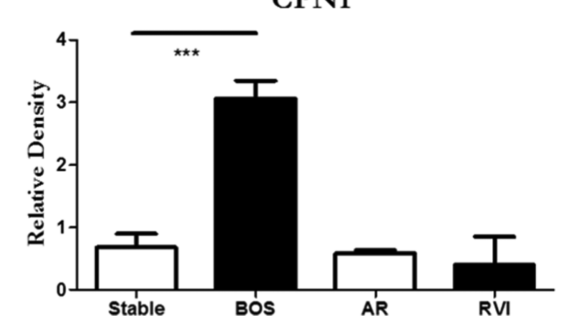

Figure 4. Western blots of significantly differential proteins (a) C3, (b) MST1, and (c) CPN1 in stable, AR, BOS, and RVI samples from exosomes from LTxRs. Densitometry of Western blots (d) C3, (e) MST1, and (f) CPN1. CD9 was used as an internal control for exosomes. The presented data are representative of at least 3 independent experiments. The C3, CPN1, and MST1 levels were normalized to CD9 levels and are shown as relative levels. Data are shown as mean \pm standard deviation $(\mathrm{SD})$. $p$-values were calculated using a two-tailed unpaired Student's $t$-test. $(* * * p<$ 0.005). Abbreviation: ST, stable; AR, acute rejection; BOS, bronchiolitis obliterans syndrome; and RVI, respiratory viral infection.

of MST1 in EVs from LTxRs with RVI suggests that MST1 can be a potential marker to differentiate RVI from AR.

The presence of immunoglobulin and complement proteins in circulating EVs isolated from LTxRs with cellular AR provides a means to differentiate cellular rejection from mixed (i.e., cellular and humoral) rejection. The presence of immunoglobulins in EVs from LTxRs with BOS suggests an important role for Abs, both against DSA and lung-associated SAgs, in the pathogenesis of BOS, as several studies have demonstrated that development of DSA and Abs to lung SAgs is an important risk factor for BOS after LTx. ${ }^{20-23}$ In addition, validation using Western blots of several proteins (C3, CPN1, and MST1), which are differentially present in LTxRs with AR, BOS, and RVI, suggests that differentiating between acute/ chronic rejection and viral infection after LTx is possible using this subset of protein markers.

\section{MATERIALS AND METHODS}

4.1. Patient Population. Lung transplant recipients at St. Joseph's Hospital and Medical Center in Phoenix, Arizona, and from Washington University Medical School in St. Louis, Missouri, were selected based on clinical diagnosis of AR, RVI (rhinovirus, metapneumovirus, and coronavirus), BOS, and stable per criterion established by ISHLT. ${ }^{24}$ This study was approved by the Institutional Review Boards of St. Joseph's Hospital and Medical Center (IRB \#PHXB16-0027-10-18), and patient samples were collected after informed consent was obtained.

4.2. Sample Collection. Blood samples were collected from patients in acid citrate dextrose solution, and plasma was isolated within $24 \mathrm{~h}$ of collection and stored at $-80^{\circ} \mathrm{C}$. LTxR demographics are summarized in Table 4.

4.3. EV Enrichment. Extracellular vesicles were isolated from $500 \mu \mathrm{L}$ of plasma by ultracentrifugation, as previously described. ${ }^{25}$ Briefly, the samples were centrifuged at $2000 \mathrm{rcf}$ $\left(20 \mathrm{~min}, 4{ }^{\circ} \mathrm{C}\right)$ followed by 2 cycles of centrifugation at 10000 $\operatorname{rcf}\left(40 \mathrm{~min}, 4^{\circ} \mathrm{C}\right)$. The supernatant was diluted with $0.5 \mathrm{~mL}$ of phosphate-buffered saline (PBS) and spun for $100000 \mathrm{rcf}$ (120 min, $\left.4{ }^{\circ} \mathrm{C}\right)$. EV pellets were resuspended in PBS. This final centrifugation step was repeated, and the EV pellets were recovered and stored at $-80{ }^{\circ} \mathrm{C}$. EV size distribution was determined using NanoSight (Malvern Panalytical, Malvern, United Kingdom; Figure 5), and EVs used in this report ranged in size from 50 to $200 \mathrm{~nm}^{26}$

4.4. Chemicals and Reagents. The chemicals and solvents used were procured from Sigma-Aldrich (St. Louis, MO) or Thermo Fisher Scientific (Waltham, MA). All chemicals were analytical reagent grade. Formic acid and solvents were liquid chromatography-mass spectrometry (LC-MS/MS) grade. Halt protease and phosphatase-inhibitor cocktail (100×) was obtained from Thermo Fisher Scientific (Waltham, MA). Sequencing-grade enzymes were purchased from Promega (Madison, WI). 
Table 4. Demographic Characteristics of 14 Lung Transplant Recipients ${ }^{a}$

\begin{tabular}{lll}
\multicolumn{1}{c}{ variable } & \multicolumn{1}{c}{$N(\%)$} & $\begin{array}{c}\text { time of sample } \\
\text { collection }\end{array}$ \\
mean age, years \pm SD & $50.3 \pm 12.2$ & \\
male sex & $7(50)$ & \\
white race & $14(100)$ & \\
bilateral LTx & $14(100)$ & \\
post-LTx diagnosis & & $1.5-2.0$ years \\
BOS & $3(21)$ & 6 months \\
AR & $3(21)$ & $12-36$ months \\
RVI & $3(21)$ & \\
stable & $5(36)$ & \\
reason for LTx by post-LTx & & \\
$\quad$ diagnosis & & \\
BOS & & \\
IPF & $3 / 3(100)$ & \\
AR & & \\
COPD & $1 / 3(33)$ & \\
IPF & $2(67)$ & \\
RVI & & \\
COPD & $2 / 3(67)$ & \\
IPF & $1 / 3(33)$ & \\
stable & & \\
COPD & & \\
IPF & & \\
$a$ & &
\end{tabular}

${ }^{a}$ Abbreviations: LTx, lung transplant; BOS, bronchiolitis obliterans syndrome; AR, acute rejection; RVI, respiratory viral infection; IPF, idiopathic pulmonary fibrosis; COPD, chronic obstructive pulmonary disease.

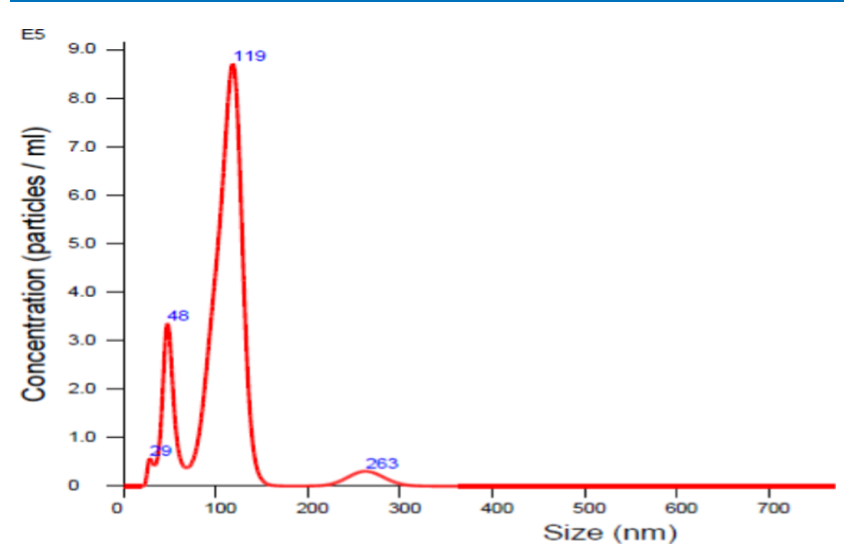

Figure 5. Representative image of size determination of exosomes using NanoSight.

4.5. Protein Extraction and Digestion. Pelleted EVs were thawed and proteins were extracted in $250 \mu \mathrm{L}$ of $25 \mathrm{mM}$ ammonium bicarbonate buffer $\left(\mathrm{NH}_{4} \mathrm{HCO}_{3}\right)$, supplemented with $1 \%$ sodium deoxycholate, $1 \times$ halt protease, and phosphatase-inhibitor cocktail. Samples were lysed by sonication for $1 \mathrm{~min}$, followed by centrifugation at $21000 \mathrm{rcf}$ (10 min, $4{ }^{\circ} \mathrm{C}$ ) to pellet any debris. The supernatant was transferred to $10 \mathrm{kD}$ Amicon Ultrafilters (Sigma-Aldrich, St Louis, MO) to perform filter-aided sample preparation for shotgun proteomic analysis. ${ }^{27,28}$ Briefly, extracted proteins were denatured with $8 \mathrm{M}$ urea, reduced in $10 \mathrm{mM}$ dithiothreitol, and alkylated in $50 \mathrm{mM}$ iodoacetamide. Samples

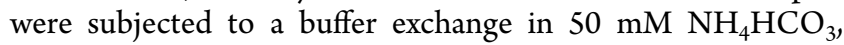
followed by overnight digestion using trypsin at a 1:50 enzyme to protein ratio at $37{ }^{\circ} \mathrm{C}$. Peptides were extracted from the filter at $14000 \mathrm{rcf}$, and the flow-through was vacuum-dried and stored at $-80{ }^{\circ} \mathrm{C}$ until LC-MS/MS analysis was performed.

4.6. LC-MS/MS Analysis. Tryptic peptides were reconstituted in $0.1 \%$ formic acid and quantified by the bicinchoninic acid assay for LC-MS/MS analysis on an Orbitrap Fusion Lumos Tribrid (Thermo, Waltham, MA) interfaced with a nanoAcquity UPLC system (Waters, Milford, $\mathrm{MA}$ ). For each sample acquired in technical triplicates, $800 \mathrm{ng}$ of peptides was first loaded on a trapping column (Acquity UPLC M-Class Trap, two-dimensional (2-D) Symmetry C18, $100 \AA$ A pore size, $5 \mu \mathrm{m}$ particle size, $20 \mathrm{~mm}$ length) and washed for $10 \mathrm{~min}$ with $99.5 \%$ Solvent A (0.1\% formic acid in water) and $0.5 \%$ solvent $\mathrm{B}(0.1 \%$ formic acid in acetonitrile $)$ at a flow rate of $7.5 \mu \mathrm{L} / \mathrm{min}$. The trapped peptides were transferred to an analytical column (Acquity UPLC M-Class Peptide BEH C18, $130 \AA$ A pore size, $1.7 \mu \mathrm{m}$ particle size, $100 \mathrm{~mm}$ length) and eluted at a flow rate of $500 \mathrm{~nL} / \mathrm{min}$ using the following gradient: $3-7 \% \mathrm{~B}$ in $1 \mathrm{~min}, 7-25 \% \mathrm{~B}$ in $25 \mathrm{~min}, 25-45 \% \mathrm{~B}$ in $10 \mathrm{~min}, 45-90 \% \mathrm{~B}$ in $0.5 \mathrm{~min}, 90 \% \mathrm{~B}$ for $1 \mathrm{~min}$, back to initial condition in $0.5 \mathrm{~min}$, and re-equilibration for $10 \mathrm{~min}$. Datadependent acquisition was performed in Top Speed mode with a duty cycle of $3 \mathrm{~s}$ and the following parameters: spray voltage of $1900 \mathrm{~V}$, ion-transfer tube temperature of $275^{\circ} \mathrm{C}$, survey scan in the Orbitrap at a resolution of $120 \mathrm{~K}$ at $200 \mathrm{~m} / z$, scan range of $400-1500 \mathrm{~m} / z$, AGC target of $2 \mathrm{E} 5$, and maximum ion injection time of $50 \mathrm{~ms}$. Every parent scan was followed by a daughter scan using high-energy collision dissociation of top abundant peaks and detection in the ion trap with following settings: quadrupole isolation mode, isolation window at 1.4 $\mathrm{m} / z$, AGC target of 5E3 with maximum ion injection time of $50 \mathrm{~ms}$, and high-energy collision energy of $35 \%$. Dynamic exclusion was set to $60 \mathrm{~s}$.

4.7. Data Analysis. Mass spectra were matched to the Homo sapiens database (2017, SwissProt/UniProtKB) using the Andromeda search engine (MaxQuant v1.6.1.0) ${ }^{29}$ with a false discovery rate (FDR) $<1 \%$, allowing up to 2 missed cleavages from trypsin. All other MaxQuant settings were set to default. Cysteine carbamidomethylation was set as a fixed modification, and variable modifications of $\mathrm{N}$-terminus acetylation and methionine oxidation were allowed. The peptides were identified using the match between runs feature enabled, and protein intensities were computed using the MaxQuant label-free quantitation (LFQ) algorithm. Iterative rank order normalization (IRON) $)^{30}$ was used to normalize LFQ intensities across all samples. For each patient, intensities were averaged if the protein was identified in 3 out of 3 technical replicates, otherwise the protein was removed from that patient. Protein intensity was $\log _{2}$-transformed, and fold change for each protein was calculated between the stable LTxR and each of the three rejection groups. Proteins annotated by MaxQuant as hits to the reverse database $(n=$ 6 proteins), potential contaminants $(n=19$ proteins), or without a unique peptide ( $n=3$ proteins) were not included for differential analysis. Statistical significance of the change in protein abundance between each pairwise analysis (stable LTxR vs each of the three rejection groups) was determined using Student's $t$-test. A Benjamini-Hochberg test for multiple corrections was also calculated. Proteins with a $\log _{2}$ (fold change) $> \pm 1$, corresponding to a 2 -fold change from the stable, and a $t$-test $p$-value $<0.05$ were deemed significantly differentially abundant. Proteins were annotated using the ExoCarta reference database. ${ }^{31}$ To identify enriched processes and pathways in each rejection condition compared to stable 
LTxRs, each protein was ordered by ranking score $(\mathrm{RS}=$ $-\log _{10}(p \text {-value })^{*} \pm 1$, where the directionality matches the fold change) from highest to lowest. Functional enrichment analysis was performed using GSEA against the Gene Ontology Resource (downloaded April 2019). ${ }^{32}$

4.8. Western Blots. Extracellular vesicles isolated with ultracentrifugation $^{25}$ were lysed using radioimmunoprecipitation assay buffer containing protease inhibitor cocktails. Protein was estimated using the bicinchoninic acid assay. Western blot was performed to validate the signatures identified by mass spectrometry. Briefly, $30 \mu \mathrm{g}$ of protein from EVs was resolved via polyacrylamide gel electrophoresis, and the proteins were transferred into a poly(vinylidene difluoride) membrane. The membrane was blocked with 5\% nonfat milk in $1 \times$ PBS and was probed with Abs to $\mathrm{C} 3$ (Abcam, anti-rabbit), CPN1 (Abcam, anti-rabbit), MST1 (Cell Signaling Technology, anti-rabbit), and CD9 (Biolegend, antimouse). Secondary Abs conjugated with horseradish peroxidase were used for detection. The blots were washed with PBS-Tween (Thermo Fisher Scientific), developed using the chemiluminescent horseradish peroxidase substrate (Amersham ECL Western Blotting Detection Kit), and exposed using an Odyssey CLx Imaging System (LI-COR Biosciences, Lincoln, NE).

\section{ASSOCIATED CONTENT}

\section{SI Supporting Information}

The Supporting Information is available free of charge at https://pubs.acs.org/doi/10.1021/acsomega.0c00859.

Details of proteins used for each pairwise analysis (Table S1); unsupervised clustering of lung transplant conditions from 35 significant proteins in lung transplant recipients with bronchiolitis obliterans syndrome (BOS), acute rejection (AR), and respiratory viral infection (RVI) compared to stable lung transplant recipients; the AR patients show clearly distinct protein profiles for the 31 differentially abundant proteins compared to the rest of the LTxR groups (Figure S1) (PDF)

\section{AUTHOR INFORMATION}

\section{Corresponding Author}

Thalachallour Mohanakumar - Norton Thoracic Institute, St. Joseph's Hospital and Medical Center, Phoenix, Arizona 85013, United States; 10 orcid.org/0000-0001-9873-4018; Email: tm.kumar@dignityhealth.org

\section{Authors}

Sandhya Bansal - Norton Thoracic Institute, St. Joseph's Hospital and Medical Center, Phoenix, Arizona 85013, United States

Marissa McGilvrey - Collaborative Center for Translational Mass Spectrometry (CCTMS), Translational Genomics Research Institute (TGen), Phoenix, Arizona 85004, United States

Krystine Garcia-Mansfield - Collaborative Center for Translational Mass Spectrometry (CCTMS), Translational Genomics Research Institute (TGen), Phoenix, Arizona 85004, United States

Ritin Sharma - Collaborative Center for Translational Mass Spectrometry (CCTMS), Translational Genomics Research
Institute (TGen), Phoenix, Arizona 85004, United States; (i) orcid.org/0000-0001-8365-9916

Ross M. Bremner - Norton Thoracic Institute, St. Joseph's Hospital and Medical Center, Phoenix, Arizona 85013, United States

Michael A. Smith - Norton Thoracic Institute, St. Joseph's Hospital and Medical Center, Phoenix, Arizona 85013, United States

Ramsey Hachem - Department of Medicine, Washington University School of Medicine, St. Louis, Missouri 63110, United States

Patrick Pirrotte - Collaborative Center for Translational Mass Spectrometry (CCTMS), Translational Genomics Research Institute (TGen), Phoenix, Arizona 85004, United States

Complete contact information is available at:

https://pubs.acs.org/10.1021/acsomega.0c00859

\section{Author Contributions}

S.B. and M.M. contributed equally to the work. T.M. and P.P. are co-senior authors. T.M. and P.P. conceived and designed the project. S.B. performed the experiments and wrote the manuscript. M.M., K.G.-M., R.S., and P.P. conducted and analyzed the experiments and revised the manuscript. R.M.B., M.A.S., and R.H. selected the patients. All authors read and approved the final manuscript.

\section{Funding}

This work was supported by the National Institutes of Health grants R21AI123034, HL092514, and HL056643 (T.M.).

\section{Notes}

The authors declare no competing financial interest.

The data sets generated and analyzed during the current study are available from the corresponding author upon reasonable request.

\section{ACKNOWLEDGMENTS}

The authors would like to thank Billie Glasscock and Clare Sonntag for their assistance in preparing and submitting the manuscript.

\section{ABBREVIATIONS USED}

Abs, antibodies; AR, acute rejection; BOS, bronchiolitis obliterans syndrome; CPN1, carboxypeptidase $\mathrm{N}$ catalytic chain; DSA, donor-specific antibody; EV, extracellular vesicle; FC, fold change; GSEA, gene set enrichment analysis; HLA, human leukocyte antigen; IGCL7, immunoglobulin lambda constant 7; LC-MS/MS, liquid chromatograph-mass spectrometry; LTx, lung transplant; LTxR, lung transplant recipient; MST1, macrophage-stimulating protein; PBS, phosphate-buffered saline; PIGR, polymeric immunoglobulin receptor; RAS, restrictive allograft syndrome; RVI, respiratory viral infection; SAg, self-antigen

\section{REFERENCES}

(1) Aziz, F.; Penupolu, S.; Xu, X.; He, J. Lung transplant in endstaged chronic obstructive pulmonary disease (COPD) patients: a concise review. J. Thorac. Dis. 2010, 2, 111-116.

(2) Yusen, R. D.; Christie, J. D.; Edwards, L. B.; Kucheryavaya, A. Y.; Benden, C.; Dipchand, A. I.; Dobbels, F.; Kirk, R.; Lund, L. H.; Rahmel, A. O.; Stehlik, J. The Registry of the International Society for Heart and Lung Transplantation: Thirtieth Adult Lung and HeartLung Transplant Report-2013; focus theme: age. J. Heart Lung Transplant 2013, 32, 965-978. 
(3) Arcasoy, S. M.; Kotloff, R. M. Lung Transplantation. N. Engl. J. Med. 1999, 340, 1081-1091.

(4) Billings, J. L.; Hertz, M. I.; Savik, K.; Wendt, C. H. Respiratory viruses and chronic rejection in lung transplant recipients. J. Heart Lung Transplant. 2002, 21, 559-566.

(5) Jakubec, P.; Žurkova, M.; Hajdová, L.; Křenková, A.; Kolek, V. The complications after lung transplantation. Vnitr. Lek. 2018, 63, 848-859.

(6) Kennel, P. J.; Saha, A.; Maldonado, D. A.; Givens, R.; Brunjes, D. L.; Castillero, E.; Zhang, X.; Ji, R.; Yahi, A.; George, I.; Mancini, D. M.; Koller, A.; Fine, B.; Zorn, E.; Colombo, P. C.; Tatonetti, N.; Chen, E. I.; Schulze, P. C. Serum exosomal protein profiling for the non-invasive detection of cardiac allograft rejection. J. Heart Lung Transplant. 2018, 37, 409-417.

(7) Shah, R.; Patel, T.; Freedman, J. E. Circulating Extracellular Vesicles in Human Disease. N. Engl. J. Med. 2018, 379, 958-966.

(8) Valadi, H.; Ekström, K.; Bossios, A.; Sjöstrand, M.; Lee, J. J.; Lötvall, J. O. Exosome-mediated transfer of mRNAs and microRNAs is a novel mechanism of genetic exchange between cells. Nat. Cell Biol. 2007, 9, 654-659.

(9) De Toro, J.; Herschlik, L.; Waldner, C.; Mongini, C. Emerging roles of exosomes in normal and pathological conditions: new insights for diagnosis and therapeutic applications. Front. Immunol. 2015, 6, No. 203.

(10) Gunasekaran, M.; Sharma, M.; Hachem, R.; Bremner, R.; Smith, M. A.; Mohanakumar, T. Circulating Exosomes with Distinct Properties during Chronic Lung Allograft Rejection. J. Immunol. 2018, 200, 2535-2541.

(11) Sharma, M.; Ravichandran, R.; Bansal, S.; Bremner, R. M.; Smith, M. A.; Mohanakumar, T. Tissue-associated self-antigens containing exosomes: Role in allograft rejection. Hum. Immunol. 2018, 79, 653-658.

(12) Naesens, M.; Li, L.; Ying, L.; Sansanwal, P.; Sigdel, T. K.; Hsieh, S. C.; Kambham, N.; Lerut, E.; Salvatierra, O.; Butte, A. J.; Sarwal, M. M. Expression of complement components differs between kidney allografts from living and deceased donors. J. Am. Soc. Nephrol. 2009, 20, 1839-1851.

(13) Sis, B.; Jhangri, G. S.; Bunnag, S.; Allanach, K.; Kaplan, B.; Halloran, P. F. Endothelial gene expression in kidney transplants with alloantibody indicates antibody-mediated damage despite lack of $\mathrm{C} 4 \mathrm{~d}$ staining. Am. J. Transplant. 2009, 9, 2312-2323.

(14) Skidgel, R. A. Structure and Function of Mammalian Zinc Carboxypeptidase. In Zinc Metalloproteases In Health and Disease; Taylor \& Francis: London, 1996.

(15) Kaetzel, C. S.; Robinson, J. K.; Chintalacharuvu, K. R.; Vaerman, J. P.; Lamm, M. E. The polymeric immunoglobulin receptor (secretory component) mediates transport of immune complexes across epithelial cells: a local defense function for IgA. Proc. Natl. Acad. Sci. U.S.A. 1991, 88, 8796-8800.

(16) Patti, M. G.; Vela, M. F.; Odell, D. D.; Richter, J. E.; Fisichella, P. M.; Vaezi, M. F. The Intersection of GERD, Aspiration, and Lung Transplantation. J. Laparoendosc. Adv. Surg. Tech. A 2016, 26, 501505.

(17) Bezerra, J. A.; Han, S.; Danton, M. J. S.; Degen, S. J. Are hepatocyte growth factor-like protein and macrophage stimulating protein the same protein? Protein Sci. 1193, 2, 666-668.

(18) Wilson, C. B.; Ray, M.; Lutz, M.; Sharda, D.; Xu, J.; Hankey, P. A. The RON receptor tyrosine kinase regulates IFN-gamma production and responses in innate immunity. J. Immunol. 2008, $181,2303-2310$

(19) Narasaraju, T.; Yang, E.; Samy, R. P.; Tan, K. S.; Moorthy, A. N.; Phoon, M. C.; van Rooijen, N.; Choi, H. W.; Chow, V. T. Combination therapy with hepatocyte growth factor and oseltamivir confers enhanced protection against influenza viral pneumonia. Curr. Mol. Med. 2014, 14, 690-702.

(20) Sundaresan, S.; Mohanakumar, T.; Smith, M. A.; Trulock, E. P.; Lynch, J.; Phelan, D.; Cooper, J. D.; Patterson, G. A. HLA-A locus mismatches and development of antibodies to HLA after lung transplantation correlate with the development of bronchiolitis obliterans syndrome. Transplantation 1998, 65, 648-653.

(21) Hachem, R. R.; Tiriveedhi, V.; Patterson, G. A.; Aloush, A.; Trulock, E. P.; Mohanakumar, T. Antibodies to K-alpha 1 tubulin and collagen $\mathrm{V}$ are associated with chronic rejection after lung transplantation. Am. J. Transplant. 2012, 12, 2164-2171.

(22) Bharat, A.; Saini, D.; Steward, N.; Hachem, R.; Trulock, E. P.; Patterson, G. A.; Meyers, B. F.; Mohanakumar, T. Antibodies to selfantigens predispose to primary lung allograft dysfunction and chronic rejection. Ann. Thorac. Surg. 2010, 90, 1094-1101.

(23) Saini, D.; Weber, J.; Ramachandran, S.; Phelan, D.; Tiriveedhi, V.; Liu, M.; Steward, N.; Aloush, A.; Hachem, R.; Trulock, E.; Meyers, B.; Patterson, G. A.; Mohanakumar, T. Alloimmunityinduced autoimmunity as a potential mechanism in the pathogenesis of chronic rejection of human lung allografts. J. Heart Lung Transplant. 2011, 30, 624-631.

(24) Meyer, K. C.; Raghu, G.; Verleden, G. M.; Corris, P. A.; Aurora, P.; Wilson, K. C.; Brozek, J.; Glanville, A. R. An international ISHLT/ ATS/ERS clinical practice guideline: diagnosis and management of bronchiolitis obliterans syndrome. Eur. Respir. J. 2014, 44, 14791503.

(25) Gunasekaran, M.; Xu, Z.; Nayak, D. K.; Sharma, M.; Hachem, R.; Walia, R.; Bremner, R. M.; Smith, M. A.; Mohanakumar, T. Donor-Derived Exosomes With Lung Self-Antigens in Human Lung Allograft Rejection. Am. J. Transplant. 2017, 17, 474-484.

(26) Théry, C.; Witwer, K. W.; Aikawa, E.; Alcaraz, M. J.; Anderson, J. D.; Andriantsitohaina, R.; Antoniou, A.; Arab, T.; Archer, F.; AtkinSmith, G. K.; Ayre, D. C.; Bach, J. M.; Bachurski, D.; Baharvand, H.; Balaj, L.; Baldacchino, S.; Bauer, N. N.; Baxter, A. A.; Bebawy, M.; Beckham, C.; Bedina Zavec, A.; Benmoussa, A.; Berardi, A. C.; Bergese, P.; Bielska, E.; Blenkiron, C.; Bobis-Wozowicz, S.; Boilard, E.; Boireau, W.; Bongiovanni, A.; Borras, F. E.; Bosch, S.; Boulanger, C. M.; Breakefield, X.; Breglio, A. M.; Brennan, M. A.; Brigstock, D. R.; Brisson, A.; Broekman, M. L.; Bromberg, J. F.; Bryl-Gorecka, P.; Buch, S.; Buck, A. H.; Burger, D.; Busatto, S.; Buschmann, D.; Bussolati, B.; Buzas, E. I.; Byrd, J. B.; Camussi, G.; Carter, D. R.; Caruso, S.; Chamley, L. W.; Chang, Y. T.; Chen, C.; Chen, S.; Cheng, L.; Chin, A. R.; Clayton, A.; Clerici, S. P.; Cocks, A.; Cocucci, E.; Coffey, R. J.; Cordeiro-da-Silva, A.; Couch, Y.; Coumans, F. A.; Coyle, B.; Crescitelli, R.; Criado, M. F.; D’Souza-Schorey, C.; Das, S.; Datta Chaudhuri, A.; de Candia, P.; De Santana, E. F.; De Wever, O.; Del Portillo, H. A.; Demaret, T.; Deville, S.; Devitt, A.; Dhondt, B.; Di Vizio, D.; Dieterich, L. C.; Dolo, V.; Dominguez Rubio, A. P.; Dominici, M.; Dourado, M. R.; Driedonks, T. A.; Duarte, F. V.; Duncan, H. M.; Eichenberger, R. M.; Ekstrom, K.; El Andaloussi, S.; Elie-Caille, C.; Erdbrugger, U.; Falcon-Perez, J. M.; Fatima, F.; Fish, J. E.; Flores-Bellver, M.; Forsonits, A.; Frelet-Barrand, A.; Fricke, F.; Fuhrmann, G.; Gabrielsson, S.; Gamez-Valero, A.; Gardiner, C.; Gartner, K.; Gaudin, R.; Gho, Y. S.; Giebel, B.; Gilbert, C.; Gimona, M.; Giusti, I.; Goberdhan, D. C.; Gorgens, A.; Gorski, S. M.; Greening, D. W.; Gross, J. C.; Gualerzi, A.; Gupta, G. N.; Gustafson, D.; Handberg, A.; Haraszti, R. A.; Harrison, P.; Hegyesi, H.; Hendrix, A.; Hill, A. F.; Hochberg, F. H.; Hoffmann, K. F.; Holder, B.; Holthofer, H.; Hosseinkhani, B.; Hu, G.; Huang, Y.; Huber, V.; Hunt, S.; Ibrahim, A. G.; Ikezu, T.; Inal, J. M.; Isin, M.; Ivanova, A.; Jackson, H. K.; Jacobsen, S.; Jay, S. M.; Jayachandran, M.; Jenster, G.; Jiang, L.; Johnson, S. M.; Jones, J. C.; Jong, A.; Jovanovic-Talisman, T.; Jung, S.; Kalluri, R.; Kano, S. I.; Kaur, S.; Kawamura, Y.; Keller, E. T.; Khamari, D.; Khomyakova, E.; Khvorova, A.; Kierulf, P.; Kim, K. P.; Kislinger, T.; Klingeborn, M.; Klinke, D. J., 2nd; Kornek, M.; Kosanovic, M. M.; Kovacs, A. F.; Kramer-Albers, E. M.; Krasemann, S.; Krause, M.; Kurochkin, I. V.; Kusuma, G. D.; Kuypers, S.; Laitinen, S.; Langevin, S. M.; Languino, L. R.; Lannigan, J.; Lasser, C.; Laurent, L. C.; Lavieu, G.; Lazaro-Ibanez, E.; Le Lay, S.; Lee, M. S.; Lee, Y. X. F.; Lemos, D. S.; Lenassi, M.; Leszczynska, A.; Li, I. T.; Liao, K.; Libregts, S. F.; Ligeti, E.; Lim, R.; Lim, S. K.; Line, A.; Linnemannstons, K.; Llorente, A.; Lombard, C. A.; Lorenowicz, M. J.; Lorincz, A. M.; Lotvall, J.; Lovett, J.; Lowry, M. C.; Loyer, X.; Lu, Q.; Lukomska, B.; Lunavat, T. R.; Maas, S. L.; Malhi, H.; Marcilla, A.; Mariani, J.; Mariscal, J.; 
Martens-Uzunova, E. S.; Martin-Jaular, L.; Martinez, M. C.; Martins, V. R.; Mathieu, M.; Mathivanan, S.; Maugeri, M.; McGinnis, L. K.; McVey, M. J.; Meckes, D. G., Jr.; Meehan, K. L.; Mertens, I.; Minciacchi, V. R.; Moller, A.; Moller Jorgensen, M.; MoralesKastresana, A.; Morhayim, J.; Mullier, F.; Muraca, M.; Musante, L.; Mussack, V.; Muth, D. C.; Myburgh, K. H.; Najrana, T.; Nawaz, M.; Nazarenko, I.; Nejsum, P.; Neri, C.; Neri, T.; Nieuwland, R.; Nimrichter, L.; Nolan, J. P.; Nolte-'t Hoen, E. N.; Noren Hooten, N.; O’Driscoll, L.; O'Grady, T.; O’Loghlen, A.; Ochiya, T.; Olivier, M.; Ortiz, A.; Ortiz, L. A.; Osteikoetxea, X.; Ostergaard, O.; Ostrowski, M.; Park, J.; Pegtel, D. M.; Peinado, H.; Perut, F.; Pfaffl, M. W.; Phinney, D. G.; Pieters, B. C.; Pink, R. C.; Pisetsky, D. S.; Pogge von Strandmann, E.; Polakovicova, I.; Poon, I. K.; Powell, B. H.; Prada, I.; Pulliam, L.; Quesenberry, P.; Radeghieri, A.; Raffai, R. L.; Raimondo, S.; Rak, J.; Ramirez, M. I.; Raposo, G.; Rayyan, M. S.; Regev-Rudzki, N.; Ricklefs, F. L.; Robbins, P. D.; Roberts, D. D.; Rodrigues, S. C.; Rohde, E.; Rome, S.; Rouschop, K. M.; Rughetti, A.; Russell, A. E.; Saa, P.; Sahoo, S.; Salas-Huenuleo, E.; Sanchez, C.; Saugstad, J. A.; Saul, M. J.; Schiffelers, R. M.; Schneider, R.; Schoyen, T. H.; Scott, A.; Shahaj, E.; Sharma, S.; Shatnyeva, O.; Shekari, F.; Shelke, G. V.; Shetty, A. K.; Shiba, K.; Siljander, P. R.; Silva, A. M.; Skowronek, A.; Snyder, O. L., 2nd; Soares, R. P.; Sodar, B. W.; Soekmadji, C.; Sotillo, J.; Stahl, P. D.; Stoorvogel, W.; Stott, S. L.; Strasser, E. F.; Swift, S.; Tahara, H.; Tewari, M.; Timms, K.; Tiwari, S.; Tixeira, R.; Tkach, M.; Toh, W. S.; Tomasini, R.; Torrecilhas, A. C.; Tosar, J. P.; Toxavidis, V.; Urbanelli, L.; Vader, P.; van Balkom, B. W.; van der Grein, S. G.; Van Deun, J.; van Herwijnen, M. J.; Van Keuren-Jensen, K.; van Niel, G.; van Royen, M. E.; van Wijnen, A. J.; Vasconcelos, M. H.; Vechetti, I. J., Jr.; Veit, T. D.; Vella, L. J.; Velot, E.; Verweij, F. J.; Vestad, B.; Vinas, J. L.; Visnovitz, T.; Vukman, K. V.; Wahlgren, J.; Watson, D. C.; Wauben, M. H.; Weaver, A.; Webber, J. P.; Weber, V.; Wehman, A. M.; Weiss, D. J.; Welsh, J. A.; Wendt, S.; Wheelock, A. M.; Wiener, Z.; Witte, L.; Wolfram, J.; Xagorari, A.; Xander, P.; Xu, J.; Yan, X.; Yanez-Mo, M.; Yin, H.; Yuana, Y.; Zappulli, V.; Zarubova, J.; Zekas, V.; Zhang, J. Y.; Zhao, Z.; Zheng, L.; Zheutlin, A. R.; Zickler, A. M.; Zimmermann, P.; Zivkovic, A. M.; Zocco, D.; Zuba-Surma, E. K. Minimal information for studies of extracellular vesicles 2018 (MISEV2018): a position statement of the International Society for Extracellular Vesicles and update of the MISEV2014 guidelines. J. Extracell. Vesicles 2018, 7, No. 1535750.

(27) Manza, L. L.; Stamer, S. L.; Ham, A.-J. L.; Codreanu, S. G.; Liebler, D. C. Sample preparation and digestion for proteomic analyses using spin filters. Proteomics 2005, 5, 1742-1745.

(28) Wiśniewski, J. R.; Zougman, A.; Nagaraj, N.; Mann, M. Universal sample preparation method for proteome analysis. Nat. Methods 2009, 6, 359-362.

(29) Cox, J.; Mann, M. MaxQuant enables high peptide identification rates, individualized p.p.b.-range mass accuracies and proteome-wide protein quantification. Nat. Biotechnol. 2008, 26, 1367-1372.

(30) Welsh, E. A.; Eschrich, S. A.; Berglund, A. E.; Fenstermacher, D. A. Iterative rank-order normalization of gene expression microarray data. BMC Bioinf. 2013, 14, No. 153.

(31) Keerthikumar, S.; Chisanga, D.; Ariyaratne, D.; Al Saffar, H.; Anand, S.; Zhao, K.; Samuel, M.; Pathan, M.; Jois, M.; Chilamkurti, N.; Gangoda, L.; Mathivanan, S. ExoCarta: A Web-Based Compendium of Exosomal Cargo. J. Mol. Biol. 2016, 428, 688-692.

(32) Subramanian, A.; Tamayo, P.; Mootha, V. K.; Mukherjee, S.; Ebert, B. L.; Gillette, M. A.; Paulovich, A.; Pomeroy, S. L.; Golub, T. R.; Lander, E. S.; Mesirov, J. P. Gene set enrichment analysis: a knowledge-based approach for interpreting genome-wide expression profiles. Proc. Natl. Acad. Sci. U.S.A. 2005, 102, 15545-15550. 